\title{
Do Political Connections Influence Investment Efficiency in Russian Companies?
}

Victoria Cherkasova

$\mathrm{PhD}$, Associate Professor

ORCID

E-mail: vcherkasova@hse.ru

School of Finance, National Research University Higher School of Economics, Moscow, Russia

\section{Anna Ivanova}

Master of Economic Sciences, Researcher, Senior Analyst

$\underline{\text { ORCID }}$

E-mail: avivanova13@gmail.com

Accenture PLC, Moscow, Russia

Journal of Corporate Finance Research, Vol. 13, No. 2, pp. 36-49 (2019)

DOI: https://doi.org/10.17323/j.jcfr.2073-0438.13.2.2019.36-49

Received 25 November 2018 | Peer-reviewed 14 February 2019 | Accepted 3 June 2019 


\section{Do Political Connections Influence Investment Efficiency in Russian Companies?}

\section{Abstract}

The question as to whether political influence can benefit the commercial activity of companies, and the related questions surrounding political corruption that arise, are of perennial fascination for persons at every level of society and in every country. With this in mind, this article seeks to explore the relationship between political connections in commercial firms and investment efficiency. This relationship will be studied on an empirical basis, and will shed some light on the actual parameters, mechanisms, and effects of political influence in the business sphere in the Russian Federation.

In this research, we consider only direct relations between business operators and the members of Russian ministries, councils, political parties, heads of the regions and cities. These relationships are categorised as being politically influential depending on the status of the politician, and whether they are active at a federal, regional or municipal level. Connections with such politicians are examined where there is evidence of direct links with company CEOs and chairmen of the boards of directors of companies.

This research is carried out on the sample of 106 Russian non-financial companies for the period 2010-2015. 44 companies from the final sample were considered as politically connected on at least one level. Some firms have connections more than at one level (11 companies). Companies have politically connected chairman of the board (36 companies) more often than connected CEO (26 companies). Using regression analysis, we determined whether the political ties in Russia have a positive or a negative impact on the investment expenditures of companies.

Interestingly, and perhaps contrary to popular belief, we identified a negative relationship between political ties and the efficiency of investment decisions for individual companies. The presence of politically-connected CEOs at federal and regional levels is seen to have a significant negative impact on investment efficiency. However, our results also indicate that the presence of politically-connected chairmen of the board which are active at the municipal level is correlated with efficient investment activity. This indicates that political influence at this level may be responsible for more prudent recommendations regarding commercial and investment decisions. Overall, it can be seen that in this sample of companies from the Russian Federation, the presence of state-tied representatives may be aligned with a tendency for companies to follow targets that are favourable for its government connections and not for the firm itself.

Although political connections have a mixed impact on the company's value, the relation with investment efficiency is primarily negative. Thus, we may reason that the government has a strong power over politically-related companies. Such influences are linked with a tendency for companies to deviate from their primary goal of value maximisation.

These results may indicate the influence of undue pressure from a government which strives to reach its own goals through the mechanism of commercial activity, or perhaps the opportunistic behaviour of individuals in management positions who are motivated towards personal political gain at the expense of the company. Political connections have a mixed effect on the company's performance and investment efficiency, and we postulate that firms establish relationships with government officials pursuing the goal to obtain more advantageous position. The links between political operators and business activity demonstrated in this research undoubtedly highlight some uncomfortable areas of discourse in the commercial sphere. On a granular level, further research into specific transactions and motivations may seem more a research area for journalists or law enforcement investigators, but this may be simply a popular prejudice. There is certainly ample opportunity for expanding the scope of this study's results. Beyond the interests of political, sociological and legal researchers, the data presented herein will be of immediate interest to persons operating in the commercial, business, and economic spheres of the Russian Federation and internationally.

Keywords: political ties, chairman of the board of directors, CEO, investment efficiency

JEL classification: G31, G32, G38 


\section{Introduction}

Political connections have a negative influence on the investment efficiency of a company. The main reason for this state of affairs is the significant power of the state. The government encourages firms to act in its interests and to reach goals favourable to it through the company's management and board of directors. However, opportunistic behaviour by top executives may also be considered a cause of inefficiency-related problems. This takes place when they do not follow the firm's primary aim of value maximisation and instead use existing corporate opportunities to gain personal benefits or to build an empire.

At the same time, political connections have a mixed effect on the company's performance and market share. Thus, firms seek to establish relationships with government officials when pursuing a goal of obtaining a more advantageous position. Moreover, some executives even become politicians themselves in order to reach this target.

The role of political connections cannot be overestimated, especially in the Russian Federation. Doing business in Russia often requires both formal and informal support from the authorities. Taking into consideration current examples of the most successful Russian entrepreneurs, we may confidently conclude that close relationships with politicians play a crucial role in the development of business projects and relationships all over the country.

The impact of political connections on a company's investment efficiency has been investigated in many empirical studies. However, even if the strength of such relations has been analysed, the level of the related government officials or politician has not been formally taken into account. It is important to emphasise that depending on the level of influence in question, the consequential experience varies. Moreover, there are, naturally, some differences in the ultimate intended goals of the politicians, and the extent of control exerted over them.

The main aim of this research is to estimate the impact of political connections on companies' investment efficiency. Many of the existing studies in the literature focus on certain categories. Those conducted by Fisman (2001) [1], Faccio et al. (2006) [2], Faccio (2010) [3], Bao et al. (2016) [4] and Su and Fung (2013) [5] analysed political connections and their influence on different parameters. The studies looked at study investment efficiency factors and ways of its measurement; Chen et al. (2009) [9], Deng et al. (2012) [10] and Pan et al. (2017) [11] who devoted their investigations to the identification of the relationship between political ties and efficiency of a company's investment decisions.

Most of the described papers are devoted to the investigation of political connections and their influence on company's performance, value, capital access and other determinants in China $[4,5,12,13]$. This is because government in that country plays a great role there in every sector of the market, and a large amount of infor- mation about political ties is recorded in local databases. These factors make the research on the Chinese market more compelling. However, political connections are also examined in Taiwan [14, 15], Thailand [16], Indonesia [1], Pakistan [17], Vietnam [18], Russia [19], and other countries $[2,3]$. Thus, the current topic is most valuable with reference to emerging countries, where markets and the economy are still developing, and the government has an opportunity to influence that process.

In contrast to previous research, in this study we determine the direct political connections of Russian public companies, and estimate the influence of political connections via the figures of the CEO and the chairman of the board of directors separately. Nevertheless, we consider three types of political connections - at the federal, regional and municipal levels. We estimate the impact of these political ties on the company's investment efficiency and test the methodology on a sample of Russian companies.

This paper has the following structure. Section 1 provides the theoretical basis of political connections, investment efficiency and the relationship between them. In Section 2 , we determine the hypotheses for further verification, we articulate the research design, and conduct a sample selection. Section 3 contains the main results of our research.

\section{Relationship between political connections and investment efficiency}

One of the most important factors for firms' successful development is the effective development of their investment decisions. Investment inefficiency may lead to disappointing results: a decrease in a company's value, reputational damage, and poor performance in general. Moreover, it may be represented in a form of under- and overinvestment. However, several determinants have an influence on such deviations and one of them is the effect of the political connections that are maintained by the firm's top executives, directors or large shareholders. Relationship with government officials may bring an advantageous position to the company, as well as creating pressure to take commercial and other decisions which are favourable to the state. Because of the mixed outcomes, the influence of the presence of political ties on company's potential investment efficiency remains a valuable matter for examination.

Most of the previous researchers focus on the relations between the existence of political ties and firm performance, while the impact of political connections on the company's investment efficiency is a relatively new topic for investigation [20]. However, this relationship can be crucial, especially for companies those operate in countries with poor legal protections, weak rule of law, and a high level of control from the government. It is important to emphasise that constituent individuals within the firm's ownership structure also have a specific effect on the outcomes of the intervention of political connections. 
For the most part, political connections negatively influence the investment efficiency of private firms, while the opposite results hold true for state-owned firms. For example, Chen et al. (2017a) [21] investigate the impact of ownership structure on the investment efficiency of a sample of companies from 64 countries in 1981-2008. They focus on the state- and foreign- types of ownership and identify that state-owned kind is associated with investment inefficiency, while there is positive correlation between the existence of foreign ownership and a company's investment efficiency. The results may be summarised in the following way: state ownership leads to an increase in agency problems and information asymmetry, while foreign ownership reduces these effects and contribute to better corporate governance. Moreover, Chen et al. detect $31.6 \%$ of politically tied firms in the sample of 506 non-financial privatised companies. The results show that the presence of political connections leads to a higher level of investment expenditure while the efficiency of these investments decreases. The authors consider a company as 'politically related' if its CEO or chairman of the board is a current or former member of local or central government or the military. State ownership is defined as indicating possession of a controlling stake in the company by the government through its agencies, ministries, state companies and bureaus. For state-owned enterprises (SOEs) that operate in the transportation, mining, and electricity industries, the percentage of politically related companies is the highest, while for private enterprises sectors the largest share of connected firms are transportation, agriculture, and manufacturing industries. These results are robust even considering the differences in institutional deployment across Chinese regions. Besides this, having a politically connected chairman or CEO in a private firm can help to check overinvesting, especially when investment opportunities are growing. On the other hand, SOEs are more likely to overinvest if the company is controlled by the local government. However, overinvestment reduces firms'values for both clusters.

Investment inefficiency of state-owned enterprises may develop due to government pressure on the company. By acting as a major stakeholder, or through the organs of management, the government can force a firm to deviate from its goal of value maximisation and to act primarily in the interests of the state. However, government does not have a direct influence on non-state-owned or politically unconnected companies. For this reason, the opposite relation exists for such enterprises. Such a finding was indicated by Chen et al. (2011b) [6] who studied the effect of government interference on companies' investment decisions in the period 2001 to 2006. Such interference was studied through the lens of the degrees of government ownership and the political background of the firms' top executives. Nevertheless, unlike Chen et al. (2009) [9], for the purpose of measurement of investment efficiency, the sensitivity of a firm's investments to Tobin's Q was implied.

However, the strength of the political connection in question is also a valuable parameter that needs to be consid- ered. Ling et al. (2016) [22] concentrate on those Chinese companies that operate in the real estate sector from 1998 to 2012. They reflect political connections in the empirical model not as a dummy variable, but as an index that shows the strength of such relations. The main results of this investigation demonstrate a stronger relation between political connectedness and the inefficiency of a firm's investment decisions for those organisations with higher political scores. It was found that such firms are more likely to overinvest and show poorer performance overall. The authors attributed those results to the managerial overconfidence that occurs from the government intervention.

On the other hand, Liu et al. (2012) [23] consider politically motivated investments that were made by Chinese companies in 1994-2010. The authors emphasise several reasons for such kind of investments. First of all, it is related to the fact of the participation of a firm's executives in the elections to the Chinese political parties. To impress the government and to show their bona fides, chairmen and CEOs usually make inefficient investments for the company. Such investments are not intended for the purpose of value maximisation. Thus, significant overinvestment takes place for the firms with politically motivated executives. Moreover, private companies seek political relations in order to reach better position through easier access to financing and other privileges. The researchers highlight the fact that that overinvestment is more critical for non-state-owned enterprises. However, after the election, the level of investments for companies decreases regardless of the ownership structure. These results are opposite to the ones obtained by Chen et al. (2009) [9].

Not only the presence, but also the termination of political ties affects a company's investment efficiency. Pan et al. (2017) [11] analyse the consequences of the elimination of a company's connections with corrupt government officials. The authors consider this process for a sample of privately-owned and state-owned firms. The opposite results were obtained for different clusters of organisations. For example, the efficiency of investment decisions of SOEs involved in a relation with corrupted politicians increased after the termination of such connections, while the opposite effect is exhibited for non-state-owned enterprises. The explanation for the positive correlation observed in state-owned firms is that without additional pressure from the government, companies can focus on value maximisation and not on the acquisition of personal benefits for executives and directors or those investments that are favourable for the state. Nevertheless, in such circumstances, privately-held firms lose political ties that help them to obtain advantageous positions in the market, and the investment efficiency of such firms declines.

Investment inefficiency can be reflected in a form of under- and overinvestments. That is why many investigators focus on the determination of such deviations. Thus, Xu et al. (2013) [24] analyse family firms in China over the from period 2000 to 2007 , and identify $12 \%$ of politically connected companies from the sample of 485 entities. The 
researchers define a firm as underinvesting if the relation between its cash flow sensitivity to investment expenditures and the level of its financial constraints is positive. If such a relation is not positive, a company is referred to the overinvesting group. Finally, the authors demonstrate that family firms are generally subject to underinvestment rather than overinvestment, and that the presence of political connections is a useful tool to address such investment inefficiency, especially for financially constrained enterprises. Zhao et al. (2013) [25] study the effect of political connections through government officials and members of the Chinese People's Political Consultative Conference (CPPCC) on the efficiency of firms' capital allocation. Ties with members of CPPCC negatively influence the investment efficiency in both ways while other types of political ties encourage only excessive investment expenditures. It was also found that after one year from the issuance of bonds, firms related to government officials decrease the level of overinvestments, and firms connected to CPPCC start to underinvest more. Another study investigating this topic was conducted by Geng (2013) [26] who determined that there is no positive correlation between the existence of political connections and access to external finance for private companies. Moreover, in case of good investment opportunities firms invest more when internal funds measured as cash flows increase, regardless of the presence of political connections. However, it was found that firms related to the government tend to invest more even when investment opportunities are poor and internal funds shrink. Indeed, the latter case may be the reason for the problem of overinvestment among politically connected companies that follow the interests of the government in the first place.

Overall, political connections decrease investment efficiency. This especially holds true for state-owned enterprises, while non-state-owned entities are trying to obtain different benefits through the establishment of political ties. Overinvestment is a more common deviation from the optimal efficient level of investments, however, the existence of mixed results demand further investigation of this topic.

\section{Research design Hypotheses development}

As we proceed to further analysis, several hypotheses shall be articulated on the basis of the literature review.

There are many factors that have an influence on the efficiency of investment decisions of a company, political connections being just one of them. Even though there have been mixed results regarding the influence of the existence of political ties on the company's value and performance, most of the research demonstrates a negative relationship between political connections with politicians and firm's investment efficiency [22, 23, 27, 28]. As discussed, that may be cause by the fact that governments have the power to exert pressure on companies via executives and directors in order to reach goals that are beneficial for the state. Our study is conducted on a sample of Russian companies, and being of an emerging market country where the government is highly influential, we therefore assume that political connections will be negatively correlated with the efficiency of firms' investment decisions.

H1: The presence of political connections decreases investment efficiency of companies.

There are several ways to measure the political connections of the company. The most common one is the existence of a relationship between a firm's executives and members of the board of directors with government officials. For a company to be recognized as politically tied, the connection of a CEO or chairman of the board is sufficient. However, these roles perform different functions and the political relations of each of them can have a different impact on the company's investment efficiency. Moreover, this distinction is important because a CEO must report to the board of directors, and the latter may impose restrictive measures on his actions. We still adhere to the belief that any sort of political connections may diminish investment efficiency, regardless of the status of the related person.

H2: A politically connected CEO/chairman of the board diminishes the investment efficiency of a company.

Following on the research of those who have studied the strength of political connections of the company $[5,17$, $22,23]$ we divide political relations into three categories according to the level of government officials in question: federal, regional and municipal. On the one hand, a company may seek a lower level of connection in order to obtain benefits in the region where the firm operates, but officials at regional and municipal levels have relatively weak power. Thus, they will not bring any advantages to the company and will not be able to exert a strong influence on investment efficiency. On the other hand, officials at the federal level have more power to force the firm to act in their own interests.

Nevertheless, some investigators view the intervention of local government through a different lens. They consider enterprises owned by the local government $[6,9,23,29]$ and have discovered that such political relations have lead to investment inefficiency, especially in the form of overinvestments. For this reason, we suppose that relations with politicians at lower levels will also have a negative impact on the efficiency of a company's investment decisions.

H3: Political connections at federal/regional/municipal level decrease the investment efficiency of companies.

Despite the fact that the political connections of a CEO and chairman of the board may have a different influence on a company's investment efficiency, the level of these connections may differ too. Even the ways of empire building and other personal benefits that can be obtained at the expense of the company by a CEO or chairman of the board of directors may vary in relation to different levels of political power [29]. That is why it is important to take into consideration the issue of personal impact. 
Hence, $\mathrm{H} 4$ and $\mathrm{H} 5$ are presented as follows:

H4: The presence of a politically connected CEO at the federal/regional/municipal level aggravates investment efficiency of companies.

H5: The presence of a politically connected chairman of the board at the federal/regional/municipal level reduces investment efficiency of companies.

\section{Methodology}

First of all, we need to determine which variables should be taken account of for further consideration. On foot of the existing research, we choose cash flow, leverage, size and the annual revenue growth of the company as control variables for further analysis (table 1). Firms with a higher level of cash flow have more funds available to make investments, thus we expect a positive value of the coefficient before cash flow. 'Leverage' indicates the portion of debt that a company has. Higher leverage indicates that the firm may experience troubles in accessing additional debt financing and it also has to pay more interest $[9,11]$. For these reasons, we anticipate a negative relationship between the financial leverage and investment expenditures of the company. Further, there are mixed results regarding the influence of the firm's size on its investments. On the one hand, small companies often suffer from financial constraints that reduce their ability to invest $[7,30]$. On the other hand, mature firms have sufficient funds to make preferable financial decisions [6]. Finally, the percentage of annual revenue growth also determines the level of investments. Companies with positive revenue growth anticipate their further development and in order to boost this expansion they start to invest more. Thus, we expect a positive influence of revenue growth on the investment expenditures.

In step one, in order to examine the relationship between the presence of political connections and company's investment efficiency we build a model as follows:

$$
\begin{aligned}
& \operatorname{Inv}_{\mathrm{i}, \mathrm{t}}=\alpha+\beta_{1} \mathrm{Q}_{\mathrm{i}, \mathrm{t}-1}+\beta_{2} \mathrm{PC}_{\mathrm{i}, \mathrm{t}}+\beta_{3} \mathrm{PC}_{\mathrm{i}, \mathrm{t}} \cdot \mathrm{Q}_{\mathrm{i}, \mathrm{t}-1}+ \\
& \beta_{4} \mathrm{CF}_{\mathrm{i}, \mathrm{t}-1}+\beta_{5} \operatorname{Size}_{\mathrm{i}, \mathrm{t}-1}+\beta_{6} \mathrm{Lev}_{\mathrm{i}, \mathrm{t}-1}+ \\
& +\beta_{7} \text { Growth }_{\mathrm{i}, \mathrm{t}-1}+\varepsilon_{\mathrm{i}, \mathrm{t}}
\end{aligned}
$$

where Inv is company's investment expenditures, $\mathrm{Q}$ is Tobin's Q, PC represents the existence of political connections and CF, Size, Lev, Growth are the control variables that display the company's cash flow, size, leverage and annual revenue growth respectively. This model will be used to test our first hypothesis.

The point of interest for us is the coefficient $\beta_{3}$ which reflects the investment efficiency of the company in the presence of political connections. Based on the reviewed literature we anticipate the negative sign of this parameter, which would indicate a decrease in the efficiency of the firm's investment decisions due to the political ties of the top executive or chairman of the board.

For further analysis, we should give a definition of the basic variables. Definitions, as well as anticipated signs of

\begin{tabular}{|c|c|c|}
\hline Variable & Definition & Anticipated sign \\
\hline Inv & $\begin{array}{l}\text { Investments of the company, measured as the sum of research and devel- } \\
\text { opment expenditures, capital expenditures and acquisition expenditures } \\
\text { minus sales of property, plant and equipment all over lagged total assets }\end{array}$ & Dependent variable \\
\hline Q & $\begin{array}{l}\text { Tobin's Q, determined as the sum of market value of } \\
\text { equity, book value of assets minus book value of equity, all over the value of } \\
\text { total assets (Jiang et al., 2011) }\end{array}$ & + \\
\hline $\mathrm{PC}$ & $\begin{array}{l}\text { A dummy variable that equals } 1 \text { if the company is politically related and } 0 \\
\text { otherwise }\end{array}$ & - \\
\hline $\mathrm{PC}_{\text {Chairman/CEO }}$ & $\begin{array}{l}\text { A dummy variable that equals } 1 \text { if the company has a politically related } \\
\text { chairman of the board/ CEO and } 0 \text { otherwise }\end{array}$ & - \\
\hline $\mathrm{PC}_{\mathrm{FED} / \mathrm{REG} / \mathrm{MUN}}$ & $\begin{array}{l}\text { A dummy variable that equals } 1 \text { if the company has political ties at the } \\
\text { federal/ regional/municipal level and } 0 \text { otherwise }\end{array}$ & - \\
\hline $\mathrm{CF}$ & $\begin{array}{l}\text { Cash flows, represented by net operating cash flows divided by lagged book } \\
\text { value of total assets of the company }\end{array}$ & + \\
\hline Size & Size of the firm, defined as natural logarithm of company's total assets & $+/-$ \\
\hline Lev & Leverage measured as total debt over total equity of the company & - \\
\hline Growth & The percentage of the company's annual revenue growth & + \\
\hline
\end{tabular}
all the other variables are presented in the table below.

Table 1. Definition of variables and their anticipated signs

Source: authors' analysis. 
In the second step we want to detect the differences in the impact of a politically related chief executive officer and chairman of the board. For this purpose, we switch the variable $P C$ that indicates the existence of political connections to the new variables $\mathrm{PC}_{\text {Chairman }}$ and $\mathrm{PC}_{\mathrm{CEO}}$ that specify the politically related person. To test our second hypothesis, the following model is implemented:

$$
\begin{aligned}
& \operatorname{Inv}_{\mathrm{i}, \mathrm{t}}=\alpha+\beta_{1} \mathrm{Q}_{\mathrm{i}, \mathrm{t}-1}+\beta_{2} \mathrm{PC}_{\mathrm{CEO}}+\beta_{3} \mathrm{PC}_{\mathrm{Chairman}}+ \\
& +\beta_{4} \mathrm{PC}_{\mathrm{CEO}} \cdot \mathrm{Q}_{\mathrm{i}, \mathrm{t}-\mathrm{l}}+\beta_{5} \mathrm{PC}_{\mathrm{Chairman}} \cdot \mathrm{Q}_{\mathrm{i}, \mathrm{t}-\mathrm{1}}+\beta_{6} \mathrm{CF}_{\mathrm{i}, \mathrm{t}-1}+ \\
& +\beta_{7} \operatorname{Size}_{\mathrm{i}, \mathrm{t}-\mathrm{1}}+\beta_{8} \operatorname{Lev}_{\mathrm{i}, \mathrm{t}-\mathrm{l}}+\beta_{9} \operatorname{Growth}_{\mathrm{i}, \mathrm{t}-\mathrm{1}}+\varepsilon_{\mathrm{i}, \mathrm{t}}
\end{aligned}
$$

We have a particular interest in the signs and values of coefficients $\beta_{4}$ and $\beta_{5}$ which represent the impact that a politically connected CEO and chairman have on the investment efficiency of the firm. We assume a negative influence of political relations and anticipate that the values of the considered coefficients will be less than zero.

The next, third step of our research is dedicated to the investigation of the influence of different levels of political connections on the efficiency of a firm's investment decisions. Thus, we divide political ties into 3 levels based on the extent of power and territorial basis: federal, regional and municipal. For each level, we employ a separate dummy variable in our model:

$$
\begin{aligned}
& \operatorname{Inv}_{\mathrm{i}, \mathrm{t}}=\alpha+\beta_{1} \mathrm{Q}_{\mathrm{i}, \mathrm{t}-1}+\beta_{2} \mathrm{PC}_{\mathrm{Fed}}+\beta_{3} \mathrm{PC}_{\mathrm{Reg}}+ \\
& +\beta_{4} \mathrm{PC}_{\mathrm{Mun}}+\beta_{5} \mathrm{PC}_{\mathrm{Fed}} \cdot \mathrm{Q}_{\mathrm{i}, \mathrm{t}-1}+\beta_{6} \mathrm{PC}_{\mathrm{Reg}} \cdot \mathrm{Q}_{\mathrm{i}, \mathrm{t}-1}+ \\
& +\beta_{7} \cdot \mathrm{PC}_{\mathrm{Mun}} \cdot \mathrm{Q}_{\mathrm{i}, \mathrm{t}-1}+\beta_{8} \mathrm{CF}_{\mathrm{i}, \mathrm{t}-1}+\beta_{9} \operatorname{Size}_{\mathrm{i}, \mathrm{t}-1}+ \\
& +\beta_{10} \mathrm{Lev}_{\mathrm{i}, \mathrm{t}-1}+\beta_{11} \operatorname{Growth}_{\mathrm{i}, \mathrm{t}-1}+\varepsilon_{\mathrm{i}, \mathrm{t}}
\end{aligned}
$$

We are interested in the sensitivity of investments to Tobin's $\mathrm{Q}$ for political connections at every level, which is represented by the coefficients $\beta_{5}, \beta_{6}$ and $\beta_{7}$. We stick to the opinion that political ties diminish the investment efficiency of a company regardless of their strength and level. Further, negative signs for the abovementioned coefficients are anticipated. However, this model is useful to test not only our third, but all three of the remaining hypotheses. To test the relation between different levels of political connections and the investment efficiency of the company, we will run this regression on a sample where political ties at different levels are emphasised. Nevertheless, to analyse the influence of a politically related CEO or chairman of the board at different levels, we separate the presented dummy variables of political connections into politically tied chief executive officer, and politically connected chairman. However, the model remains essentially the same.

\section{Sample selection}

We collected data on financial indicators for 143 Russian listed firms from the Capital IQ database. Only non-financial companies were taken into consideration. Information about political ties of firms' top executives was gathered manually from companies' annual reports and other open sources. The main issue that was met during the data gathering is that companies disclose biographical information about its management and board of directors only for the last 5 years. Thus, data about political connections were obtained mostly from internet search engines. Our sample covers a period from 2010 to 2015. Companies that had no annual reports or available information about their top executives were excluded from the

\begin{tabular}{|c|c|}
\hline Industry & Number of companies \\
\hline Industrials & 9 \\
\hline Telecommunication Services & 4 \\
\hline Energy & 13 \\
\hline Materials & 25 \\
\hline Utilities & 31 \\
\hline Consumer Discretionary & 10 \\
\hline Consumer Staples & 9 \\
\hline Real Estate & 2 \\
\hline Healthcare & 3 \\
\hline Sum & 106 \\
\hline
\end{tabular}
original sample, as well as firms lacking financial information. Thus, only 106 companies were captured for further analysis. Almost $50 \%$ of the selected companies operate in the utilities and materials industries, while the rest covers 7 different sectors as represented below (Table 2).

Table 2. Primary industries of companies' operations

Source: authors' analysis.

The primary variable for this study is political connectedness. Following Li et al. (2006) [12], Fan et al. (2007) [13] and Bao et al. (2016) [4] the company is defined as politically tied if its CEO or chairman of the board of directors is a current or former government official. We consider only direct relations with the members of Russian ministries, councils, political parties, heads of the regions and cities. We do not take into account indirect relations, in order to avoid subjective and biased estimations.

Table 3. Share of politically connected firms by year, $\%$

\begin{tabular}{ccc} 
Year & Connected & Non-connected \\
\hline 2010 & 33 & 67 \\
\hdashline 2011 & 30 & 70 \\
\hdashline 2012 & 28 & 72 \\
\hdashline 2013 & 24 & 76 \\
\hdashline 2014 & 30 & 70 \\
\hdashline 2015 & 30 & 70
\end{tabular}

Source: authors' analysis. 
Moreover, it is very hard to obtain and collect all the information about family, friends and other persons who are closely related to government officials. Thus, the amount of politically connected companies in the sample was quite stable over the considered period: $29 \%$ on average. That aligns with the data collected by other researchers on a sample of companies from Russia and $63 \%$ of other countries (Table 3) [7,21]. The largest share of connected firms was evident in 2010 and the lowest share in 2013. At the same time, 44 companies from the final sample were considered as politically connected at least once over the investigated period. Moreover, 30 of them have political ties at the federal level, 18 at the regional level, and 7 at the municipal level (Table 4). As can be seen, some firms have connections at more than one level that can put them in an advantageous position.

Table 4. The presence of political ties over 2010-2015

\begin{tabular}{|c|c|c|}
\hline Status & Number of companies & Percentage, $\%$ \\
\hline Non-connected politically & 62 & 58 \\
\hline Connected politically & 44 & 42 \\
\hline - at federal level & 30 & 28 \\
\hline - at regional level & 18 & 17 \\
\hline - at municipal level & 7 & 7 \\
\hline Overall & 106 & 100 \\
\hline
\end{tabular}

Source: authors' analysis.

Table 5. The number of companies with politically connected top executives over 2010-2015

\begin{tabular}{|c|c|c|}
\hline Politically connected & CEO & Chairman of Board \\
\hline Overall & 26 & 36 \\
\hline - at federal level & 10 & 23 \\
\hline - at regional level & 12 & 10 \\
\hline - at municipal level & 4 & 3 \\
\hline
\end{tabular}

Source: authors' analysis.

Finally, overall, companies at the federal level have a politically connected chairman of the board more often than a connected CEO, while at the regional and municipal levels politically related CEOs are more common (Table 5).

The descriptive statistics of the investigated parameters presented in table 6 demonstrate the mean values of variables. It is important to take note that, on average, these companies:
- invest in the amount of $13 \%$ of total assets;

- have a cash flow that equals $10 \%$ of total assets;

- $\quad$ have a low debt load (total debt is 33\% of total assets);

- have an annual increase in revenue of $16 \%$;

- have a good investment opportunities and growth potential (Tobin's Q is higher than 1).

Table 6. Descriptive statistics

\begin{tabular}{|c|c|c|c|c|c|}
\hline Variable & & Mean & Std. Dev. & Min & Max \\
\hline \multirow{3}{*}{ Investments } & overall & 0.1315169 & 0.1810705 & -0.5667444 & 1.412442 \\
\hline & between & & 0.1056058 & -0.0574078 & 0.5568823 \\
\hline & within & & 0.147729 & -0.4194523 & 1.398692 \\
\hline \multirow{3}{*}{ Cash flow } & overall & 0.1034553 & 0.1315818 & -0.4210463 & 0.7101095 \\
\hline & between & & 0.0936104 & -0.1771722 & 0.3830587 \\
\hline & within & & 0.0932716 & -0.3715313 & 0.5714298 \\
\hline
\end{tabular}




\begin{tabular}{|c|c|c|c|c|c|}
\hline Variable & & Mean & Std. Dev. & Min & $\operatorname{Max}$ \\
\hline \multirow{3}{*}{ Tobin's Q } & overall & 1.20186 & 0.7554601 & 0.0594833 & 7.009595 \\
\hline & between & & 0.8257317 & 0.2210095 & 7.009595 \\
\hline & within & & 0.3912746 & -1.003028 & 5.056125 \\
\hline \multirow{3}{*}{ Size } & overall & 11.00521 & 1.954596 & 5.608006 & 16.65178 \\
\hline & between & & 1.932205 & 6.387913 & 16.29719 \\
\hline & within & & 0.3367227 & 9.440665 & 12.27576 \\
\hline \multirow{3}{*}{ Leverage } & overall & 0.3292781 & 0.3189066 & 0 & 4.576138 \\
\hline & between & & 0.2781524 & 0 & 2.324039 \\
\hline & within & & 0.1567214 & -0.7522612 & 2.581377 \\
\hline \multirow{3}{*}{ Revenue growth } & overall & 15.72527 & 80.10551 & -98.1 & 1274.7 \\
\hline & between & & 35.65318 & -23.71057 & 314.7 \\
\hline & within & & 71.84487 & -379.6747 & 975.7253 \\
\hline
\end{tabular}

Source: authors' analysis.

Table 7. Correlation matrix

\begin{tabular}{|c|c|c|c|c|c|c|}
\hline & Investments & Cash flow & Tobin's Q & Size & Leverage & Revenue growth \\
\hline Investments & 1.0000 & & & & & \\
\hline Cash flow & $0.2714^{\star}$ & 1.0000 & & & & \\
\hline Tobin's Q & 0.0444 & $0.2317^{\star}$ & 1.0000 & & & \\
\hline Size & $0.2098^{\star}$ & $0.2875^{\star}$ & $-0.1520^{\star}$ & 1.0000 & & \\
\hline Leverage & $-0.0790^{*}$ & $-0.2130^{\star}$ & $0.3083^{*}$ & -0.0197 & 1.0000 & \\
\hline Revenue growth & $0.0916^{\star}$ & 0.0501 & 0.0549 & -0.0332 & 0.0410 & 1.0000 \\
\hline
\end{tabular}

${ }^{*}$ is indicating a significance level at $5 \%$.

Source: authors' analysis.

The correlation matrix represented below shows that all the considered variables have a positive relation with the amount of company's investments (Table 7). However, leverage is negatively related with investments, which aligns with the existing literature and our assumptions.

For the purpose of this research we follow Chen et al. (2011b) [6], Xie (2015) [31], Wan et al. (2015) [32], Chen et al. (2017a) [21] and employ the sensitivity of investment expenditures to a company's investment opportunities defined through Tobin's $\mathrm{Q}$ as a proxy for the firm's investment efficiency.

\section{Empirical results}

Consistent with step one of our research, Table 8 represents the results of our first model. This helps us to inves- tigate the relationship between political connections and the efficiency of the firm's investment decisions.

The relation between investment expenditures and Tobin's $\mathrm{Q}$ is positive and significant at the $1 \%$ level of significance. In case of positive investment opportunities, companies boost their investments. That determines the efficiency of their investment expenditures. Similar results were obtained by several other researchers $[6,11,31]$. The relationship between political connections and investment expenditures is positive but insignificant. That means that this kind of connection does not have an influence on the amount of company's investments. However, the coefficient before $P C \cdot Q_{i, t-1}$ is negative and significant at a $5 \%$ level. That implies that the presence of political connections decreases the investment efficiency of the firm. Such 
relation may be caused by the pressure that government exerts on the company through the related entities. The state has great power in Russia and can force firms to act in its own interests.

Table 8. The influence of political connections on the investment efficiency

\begin{tabular}{|c|c|}
\hline Dependent variable & Investments \\
\hline \multicolumn{2}{|l|}{ Independent variables } \\
\hline \multirow{2}{*}{$P C \cdot Q_{i, t-1}$} & $-0.06060^{\star *}$ \\
\hline & $(0.02861)$ \\
\hline \multirow{2}{*}{$\mathrm{Q}_{\mathrm{i}, \mathrm{t}-1}$} & $0.11278^{\star * *}$ \\
\hline & $(0.02309)$ \\
\hline \multirow{2}{*}{$\mathrm{CF}_{\mathrm{i}, \mathrm{t}-1}$} & 0.01617 \\
\hline & $(0.05736)$ \\
\hline \multirow{2}{*}{ Size $_{\mathrm{i}, \mathrm{t}-1}$} & $0.01384^{\star * \star}$ \\
\hline & $(0.00523)$ \\
\hline \multirow{2}{*}{$\operatorname{Lev}_{i, t-1}$} & $-0.16358^{\star * *}$ \\
\hline & $(0.03478)$ \\
\hline \multirow{2}{*}{ Growth $_{\mathrm{i}, \mathrm{t}-1}$} & 0.00004 \\
\hline & $(0.00004)$ \\
\hline \multirow{2}{*}{$\mathrm{PC}_{\mathrm{i}, \mathrm{t}}$} & 0.01074 \\
\hline & $(0.03447)$ \\
\hline \multirow{2}{*}{ Intercept } & -0.07046 \\
\hline & $(0.06811)$ \\
\hline $\mathrm{N}$ of obs & 551 \\
\hline R-squared & 0.2420 \\
\hline Wald chi2 & 53.52 \\
\hline Prob $>$ F & 0.0000 \\
\hline
\end{tabular}

${ }^{* * *}$ and ${ }^{* *}$ indicate $1 \%, 5 \%$ significance levels respectively.

Source: authors' analysis.

On the other hand, companies can take this initiative on their own to get patronage from the state that will lead them to the advantageous positions. Overall, our first hypothesis is not rejected and the obtained results align with previous investigations. Furthermore, cash flow has a positive but insignificant effect on the amount of investments. Lagged value of cash flow does not have an impact on the level of a company's investments in the current period. Thus, financial constraints in the previous year have no valuable effect on the investment expenditures in the considered year. Size is positively related with investment expenditures, which can be explained by the fact that smaller companies invest more prudently because of lack of available funds for investments while larger companies do not have such barriers and invest more [9, 10, 24]. Financial leverage has a negative and significant impact on the investment expenditures, as was predicted by several researchers $[10,11,28]$. For the most part, it is again related to the financial constraints that companies experience. Larger amounts of debt leads to higher interest payments and a lower ability to obtain additional financing. Moreover, we reveal a positive but insignificant influence of the revenue growth on the level of investments.

In the second step, we investigate the impact of the presence of a politically tied chief executive officer or chairman of the board on the investment efficiency of the company separately. The results are presented in the Table 9.

Even though both politically connected CEOs and chairmen have a negative influence on the efficiency of a company's investments, only a relation with the chief executive officer is significant. Such results demonstrate that either the government enforces the firm to act in its interests through the chairman or CEO, but the state achieve its goals only through the latter. Cases of empire building and retrieval of personal benefits may take place. The level of significant impact through the CEO may be caused by the fact that he has a power of decision making in the company, while a chairman of the board has the same limited responsibilities as other directors. In this situation, it is much harder for him to gain personal benefits, while a chief executive officer is more independent in his decisions. Thus, our second hypothesis is partially confirmed and the presence of politically tied CEO decreases the investment efficiency of the company.

What is more, the presence of a politically connected CEO is positively associated with the amount of a company's investment expenditures. A firm with a politically related top executive has easier access to external capital, faces less financial constraints and has a better performance overall, which supports its investments. However, the efficiency of such investments decreases, which aligns with the results obtained by Chen et al. (2017a) [21].

Table 9. The influence of a politically connected Chairman of the board or CEO on investment efficiency

\begin{tabular}{|c|c|}
\hline Dependent variable & Investments \\
\hline \multicolumn{2}{|l|}{ Independent variables } \\
\hline $\mathrm{PC}_{\text {chairmav }} \cdot \mathrm{Q}_{\mathrm{i}, \mathrm{t}-1}$ & $\begin{array}{l}-0.02477 \\
(0.02371)\end{array}$ \\
\hline $\mathrm{PC}_{\mathrm{CEO}} \cdot \mathrm{Q}_{\mathrm{i}, \mathrm{t}-1}$ & $\begin{array}{c}-0.12548^{\star \star *} \\
(0.03692)\end{array}$ \\
\hline$Q_{i, t-1}$ & $\begin{array}{c}0.10754^{* * *} \\
(0.02150)\end{array}$ \\
\hline $\mathrm{CF}_{\mathrm{i}, \mathrm{t}-1}$ & $\begin{array}{c}0.01805 \\
(0.05575)\end{array}$ \\
\hline
\end{tabular}




\begin{tabular}{|c|c|}
\hline Size $_{i, t-1}$ & $\begin{array}{l}0.01030^{\star *} \\
(0.00530)\end{array}$ \\
\hline $\operatorname{Lev}_{\mathrm{i}, \mathrm{t}-1}$ & $\begin{array}{c}-0.16379^{\star * *} \\
(0.03241)\end{array}$ \\
\hline Growth $_{\mathrm{i}, \mathrm{t}-1}$ & $\begin{array}{c}0.00004 \\
(0.00004)\end{array}$ \\
\hline $\mathrm{PC}_{\text {chairman } \mathrm{i}, \mathrm{t}}$ & $\begin{array}{c}0.00503 \\
(0.03107)\end{array}$ \\
\hline $\mathrm{PC}_{\mathrm{CEO} \mathrm{i}, \mathrm{t}}$ & $\begin{array}{l}0.08946^{*} \\
(0.05276)\end{array}$ \\
\hline Intercept & $\begin{array}{l}-0.02827 \\
(0.06839)\end{array}$ \\
\hline $\mathrm{N}$ of obs & 551 \\
\hline R-squared & 0.2664 \\
\hline Wald chi2 & 85.71 \\
\hline Prob $>$ F & 0.0000 \\
\hline
\end{tabular}

\begin{tabular}{|c|c|}
\hline $\operatorname{Lev}_{\mathrm{i}, \mathrm{t}-1}$ & $\begin{array}{c}-0.16407^{\star * *} \\
(0.03184)\end{array}$ \\
\hline Growth $_{\mathrm{i}, \mathrm{t}-1}$ & $\begin{array}{c}0.0000496 \\
(0.0000428)\end{array}$ \\
\hline $\mathrm{PC}_{\text {Fed i,t }}$ & $\begin{array}{c}0.01392 \\
(0.03547)\end{array}$ \\
\hline $\mathrm{PC}_{\text {Reg } \mathrm{i}, \mathrm{t}}$ & $\begin{array}{c}0.07169 \\
(0.05080)\end{array}$ \\
\hline $\mathrm{PC}_{\mathrm{Muni} \mathrm{i}, \mathrm{t}}$ & $\begin{array}{c}0.09793 \\
(0.09943)\end{array}$ \\
\hline Intercept & $\begin{array}{l}-0.06432 \\
(0.06673)\end{array}$ \\
\hline $\mathrm{N}$ of obs & 551 \\
\hline R-squared & 0.2615 \\
\hline Wald chi2 & 76.31 \\
\hline Prob $>F$ & 0.0000 \\
\hline
\end{tabular}

${ }^{* * *},{ }^{* *},{ }^{*}$ indicate $1 \%, 5 \%, 10 \%$ significance levels respectively.

Source: authors' analysis.

In the third step we consider the federal, regional and municipal tiers of the Russian government. Each of these levels might have an individual influence on the amount of investment expenditures and their efficiency as well (Table 10).

Table 10. The influence of different levels of political connections on investment efficiency

\begin{tabular}{|c|c|}
\hline Dependent variable & Investments \\
\hline \multicolumn{2}{|l|}{ Independent variables } \\
\hline $\mathrm{PC}_{\mathrm{Fed}} \cdot \mathrm{Q}_{\mathrm{i}, \mathrm{t}-1}$ & $\begin{array}{l}-0.04462^{\star} \\
(0.02601)\end{array}$ \\
\hline $\mathrm{PC}_{\text {Reg }} \cdot \mathrm{Q}_{\mathrm{i}, \mathrm{t}-1}$ & $\begin{array}{c}-0.12358^{\star * *} \\
(0.04717)\end{array}$ \\
\hline $\mathrm{PC}_{\text {Mun }} \cdot \mathrm{Q}_{\mathrm{i}, \mathrm{t}-1}$ & $\begin{array}{l}-0.17206^{*} \\
(0.10245)\end{array}$ \\
\hline $\mathrm{Q}_{\mathrm{i}, \mathrm{t}-1}$ & $\begin{array}{c}0.11403^{\star * *} \\
(0.02247)\end{array}$ \\
\hline $\mathrm{CF}_{\mathrm{i}, \mathrm{t}-1}$ & $\begin{array}{c}0.01620 \\
(0.05663)\end{array}$ \\
\hline Size $_{\mathrm{i}, \mathrm{t}-1}$ & $\begin{array}{c}0.01318^{\star * *} \\
(0.00512)\end{array}$ \\
\hline
\end{tabular}

${ }^{* * *},{ }^{* *},{ }^{*}$ indicate $1 \%, 5 \%, 10 \%$ significance levels respectively.

Source: authors' analysis.

We confirmed our previous results about the negative relationship between political connections and the investment efficiency of the company. Importantly, this relation is maintained regardless of the level of related government officials. Coefficients of $\mathrm{PC}_{\mathrm{Fed}} \bullet \mathrm{Q}_{\mathrm{i}, \mathrm{t}-1}, \mathrm{PC}_{\mathrm{Reg}} \bullet \mathrm{Q}_{\mathrm{i}, \mathrm{t}-1}$ and $\mathrm{PC}_{\mathrm{Mun}} \bullet \mathrm{Q}_{\mathrm{i}, \mathrm{t}-1}$ are all negative and significant. Thus, consistent with our third hypothesis, the existence of the political connections at different levels eliminates the efficiency of a company's investment decisions. The level of influence increases with the lowering of the government tier. Relations with the politicians at the federal level have a weaker impact on the investment efficiency compared to politicians at the regional level. Nevertheless, connections with government officials at the municipal level affect the efficiency of investments the most. The reason for that may be the fact that control over municipal politicians is more tenuous and it is easier to hide the fact of enforcement or the pursuing of personal benefits. Companies can achieve smaller goals in support of the local government with less effort in comparison with countrywide aims. As such, we determine that any kind of considered connections does not have an effect on the value of company's investments.

Further, we analyse the same division of government levels in the context of the related person from the company's side. We investigate whether political connections, through a chief executive officer or chairman of the board of directors have an influence on the company's investment efficiency. 
As can be seen from Table 11 the presence of a politically related chief executive officer or chairman of the board of directors has a mixed influence on the value of company's investments. Only the existence of a politically connected chairman at the regional level is of consequence. A chairman of the board that is a current or former government official at the regional level has a negative impact on the amount of investments, while there is no effect on their efficiency. The presence of a politically connected chairman at the municipal level is positively related to the efficiency of a company's investments. This may be due to easy access to information and financing, or investment plans of the local government that help firms to make more prudent strategy plans and recommendations for investment decisions. On the other hand, politically connected CEOs at the municipal level do not have any influence on the investment efficiency of the company. At the same time, a chief executive officer's ties with the state at the federal and regional level correlate with a decline in the efficiency of the firm's investment decisions. In this case, we confirmed the results that were obtained earlier that government has an influence on the company mostly through its CEO. A consideration of the politically connected chief executive and chairman of the board separately gives us an understanding that the firm's investment efficiency is affected at any level of the state's representatives.

Table 11. The impact of CEO's/Chairman's political connections at different levels on company's investment efficiency

\begin{tabular}{|c|c|c|}
\hline $\begin{array}{l}\text { Dependent variable } \\
\text { Impact of connected }\end{array}$ & $\begin{array}{l}\text { Investments } \\
\text { CEO }\end{array}$ & Chairman \\
\hline \multicolumn{3}{|l|}{$\begin{array}{l}\text { Independent varia- } \\
\text { bles }\end{array}$} \\
\hline $\mathrm{PC}_{\mathrm{Fed}} \cdot \mathrm{Q}_{\mathrm{i}, \mathrm{t}-1}$ & $\begin{array}{l}-0.03151^{* * *} \\
(0.00939)\end{array}$ & $\begin{array}{l}-0.00553 \\
(0.00615)\end{array}$ \\
\hline $\mathrm{PC}_{\text {Reg }} \cdot \mathrm{Q}_{\mathrm{i}, \mathrm{t}-1}$ & $\begin{array}{l}-0.05760^{\star * *} \\
(0.01723)\end{array}$ & $\begin{array}{l}0.06661 \\
(0.04326)\end{array}$ \\
\hline $\mathrm{PC}_{\mathrm{Mun}} \cdot \mathrm{Q}_{\mathrm{i}, \mathrm{t}-1}$ & $\begin{array}{l}-0.05349 \\
(0.08452)\end{array}$ & $\begin{array}{l}0.27518^{\star *} \\
(0.12842)\end{array}$ \\
\hline $\mathrm{Q}_{\mathrm{i}, \mathrm{t}-1}$ & $\begin{array}{l}0.08937^{\star * *} \\
(0.01294)\end{array}$ & $\begin{array}{l}0.08003^{* * *} \\
(0.02012)\end{array}$ \\
\hline $\mathrm{CF}_{\mathrm{i}, \mathrm{t}-1}$ & $\begin{array}{l}0.04357 \\
(0.05727)\end{array}$ & $\begin{array}{l}0.00855 \\
(0.05850)\end{array}$ \\
\hline Size $_{i, t-1}$ & $\begin{array}{l}0.00876^{\star} \\
(0.00508)\end{array}$ & $\begin{array}{l}0.01231^{\star *} \\
(0.00572)\end{array}$ \\
\hline $\operatorname{Lev}_{i, t-1}$ & $\begin{array}{l}-0.13304^{\star * *} \\
(0.02666)\end{array}$ & $\begin{array}{l}-0.12229^{\star * *} \\
(0.03395)\end{array}$ \\
\hline Growth $_{\mathrm{i}, \mathrm{t}-1}$ & $\begin{array}{l}0.00005^{\mathrm{a}} \\
(0.00004)\end{array}$ & $\begin{array}{l}0.00004 \\
(0.00004)\end{array}$ \\
\hline
\end{tabular}

\begin{tabular}{|c|c|c|}
\hline $\mathrm{PC}_{\mathrm{Fed} \mathrm{i}, \mathrm{t}}$ & $\begin{array}{l}0.02151 \\
(0.03014)\end{array}$ & $\begin{array}{l}-0.01424 \\
(0.02285)\end{array}$ \\
\hline $\mathrm{PC}_{\mathrm{Reg} i, t}$ & $\begin{array}{l}0.03989 \\
(0.03807)\end{array}$ & $\begin{array}{l}-0.07638^{\star *} \\
(0.03946)\end{array}$ \\
\hline $\mathrm{PC}_{\text {Mun i,t }}$ & $\begin{array}{c}-0.03934 \\
(0.07863)\end{array}$ & $\begin{array}{l}-0.02149 \\
(0.06486)\end{array}$ \\
\hline Intercept & $\begin{array}{l}-0.00649 \\
(0.06246)\end{array}$ & $\begin{array}{l}-0.03838 \\
(0.07358)\end{array}$ \\
\hline $\mathrm{N}$ of obs & 543 & 543 \\
\hline R-squared & 0.2790 & 0.2416 \\
\hline Wald chi2 & 80.33 & 80.38 \\
\hline Prob $>$ F & 0.0000 & 0.0000 \\
\hline
\end{tabular}

${ }^{* * *},{ }^{* *},{ }^{*}$ and ${ }^{a}$ indicate $1 \%, 5 \%, 10 \%$ and $15 \%$ significance levels respectively.

Source: authors' analysis.

To conclude, our fourth hypothesis is partially confirmed: a company's investment efficiency is eliminated in the presence of a politically connected CEO at the federal and municipal level. Our last hypothesis, however, is rejected because we did not find a significant negative influence of a politically tied chairman of the board of directors. However, we did discover a positive effect of such connections at the municipal level.

\section{Conclusion}

We identified a negative influence of political connections on the investment efficiency of the company, on a basis of the existing empirical and theoretical literature. Despite the presence of various approaches to measuring political connections, the most common one focuses around the previous and current working experience of a firm's chief executive officer or chairman of the board of directors. Political connections have a mixed impact on the company's value and performance. However, the relation to investment efficiency is always negative. That may be caused by the fact that government has a strong influence over the politically related companies. Such an influence enforces a firm to deviate from its primary goal of value maximisation. Moreover, managers can act in the interests of the state in order to impress people in power and thereby attain more personal benefits.

This paper investigates the relationship between political connections and the investment efficiency of companies. Consistent with the obtained results the following conclusions can be made:

- $\quad$ on average, $29 \%$ of public companies are politically connected;

- the presence of political connections has a negative influence on a firm's investment efficiency (that is manifested in a form of underinvestment); 
- a politically related chairman of the board has no impact on the efficiency of investment decisions while CEO is negatively related to it;

- political ties at the federal, regional and municipal levels decrease investment efficiency;

- the presence of a politically connected chief executive officer at the federal and regional level declines the efficiency of investments;

- the existence of a politically tied chairman of the board enhances company's investment efficiency.

Possible explanations of such outcomes are related to the strong position of the government in Russia and the opportunistic behaviour of a firm's top executives. Moreover, the top management of a company may focus on pursuing personal goals and obtaining additional benefits. It is also the case that empire-building motives of a CEO can lead to a decrease in investment efficiency. Besides, companies can use the relations with authorities at the municipal level in order to obtain a more advantageous position in the market.

\section{References}

1. Fisman R. Estimating the value of political connections. The American Economic Review. 2001;91(4):1095-1102. DOI: 10.1257/aer.91.4.1095

2. Faccio M., Masulis R.W., McConnell J. Political connections and corporate bailouts. The Journal of Finance. 2006;61(6):2597-2635. DOI: 10.1111/j.15406261.2006.01000.x

3. Faccio M. Differences between politically connected and nonconnected firms: A cross-country analysis. Financial Management. 2010;39(3):905-928. DOI: 10.1111/j.1755-053X.2010.01099.x

4. Bao X., Johan S., Kutsuna K. Do political connections matter in accessing capital markets? Evidence from China. Emerging Markets Review. 2016;29:24-41. DOI: 10.1016/j.ememar.2016.08.009

5. Su Z., Fung H. Political connections and firm performance in Chinese companies. Pacific Economic Review. 2013;18(3):283-317. DOI: 10.1111/14680106.12025

6. Chen S., Sun Z., Tang S., Wu D. Government intervention and investment efficiency: Evidence from China. Journal of Corporate Finance. 2011;17(2):259271. DOI: 10.1016/j.jcorpfin.2010.08.004

7. Chen T., Xie L., Zhang Y. How does analysts' forecast quality relate to corporate investment efficiency? Journal of Corporate Finance. 2017;43:217-240. DOI: 10.1016/j.jcorpfin.2016.12.010

8. Chen C., Ding Y., Kim C. High-level politically connected firms, corruption, and analyst forecast accuracy around the world. Journal of International Business Studies. 2010;41(9):1505-1524. DOI: $10.1057 /$ jibs.2010.27
9. Chen S., Sun Z., Tang S., Wu D. Political connections and investment efficiency: Evidence from SOEs and private enterprises in China. 2009. URL: https://www. researchgate.net/publication/255626309_Political_ Connections_and_Investment_Efficiency_Evidence_ from_SOEs_and_Private_Enterprises_in_China

10. Deng L., Li S., Liu H. How does political connection help during crisis? Evidence from Chinese private firms. 2012. URL: https://editorialexpress. com/cgi-bin/conference/download.cgi?db_ name $=$ CICF2014\&paper_id $=781$

11. Pan X., Tian G.G. Political connections and corporate investments: Evidence from the recent anti-corruption campaign in China. Journal of Banking \& Finance. 2017. In press. DOI: 10.1016/j. jbankfin.2017.03.005

12. Li H., Meng L., Zhang J. Why do entrepreneurs enter politics? Evidence from China. Economic Inquiry. 2006;44(3):559-578. DOI: 10.1093/ei/cbj031

13. Fan J.P.H., Wong T.J., Zhang T. Politically connected CEOs, corporate governance, and Post-IPO performance of China's newly partially privatized firms. Journal of Financial Economics. 2007;84(2):330-357. DOI: 10.1016/j. jfineco.2006.03.008

14. Shen C.-H., Luo F., Huang D. Analysis of earnings management influence on the investment efficiency of listed Chinese companies. Journal of Empirical Finance. 2015;34:60-78. DOI: 10.1016/j. jempfin.2015.08.003

15. Lin C.-Y., Ho P.-H., Shen C.-H., Wang Y.-C. Political connection, government policy, and investor trading: Evidence from an emerging market. International Review of Economics \& Finance. 2016;42:153-166. DOI: $10.1016 /$ j.iref.2015.09.008

16. Civilize S., Wongchoti U., Young M. Political connection and stock returns: A longitudinal study. The Financial Review. 2015;50(1):89-119. DOI: 10.1111/fire.12061

17. Saeed A., Belghitar Y., Clark E. Political connections and leverage: Firm level evidence from Pakistan. Managerial and Decision Economics. 2015;36(6):364383. DOI: $10.1002 /$ mde. 2674

18. O’Toole C.M., Morgenroth E.L.W., Ha T.T. Investment efficiency, state-owned enterprises and privatisation: Evidence from Viet Nam in Transition. Journal of Corporate Finance. 2016;37:93-108. DOI: 10.1016/j.jcorpfin.2015.12.011

19. Fadeev P. Political connections and evolution of ownership structure in Russian industry. New Economic School. Working Paper. 2008;(099). URL: https:/old.nes.ru/dataupload/files/programs/econ/ preprints/2008/Fadeev.pdf 
20. Gladysheva A., Kishilova Y. The influence of political connections and government ownership on firm performance: Evidence from Russia. Korporativnye finansy = Journal of Corporate Finance Research. 2018;12(1):20-43. DOI: 10.17323/j.jcfr.20730438.12.1.2018.20-43 (in Russ.).

21. Chen R., Ghoul S.E., Guedhami O., Wang H. Do state and foreign ownership affect investment efficiency? Evidence from privatizations. Journal of Corporate Finance. 2017;42:408-421. DOI: 10.1016/j. jcorpfin.2014.09.001

22. Ling L., Zhou X., Liang Q., Song P., Zeng H. Political connections, overinvestments and firm performance: Evidence from Chinese listed real estate firms. Finance Research Letters. 2016;18:328-333. DOI: 10.1016/j.frl.2016.05.009

23. Liu Q., Luo W., Xu N. Political motivation, overinvestment, and firm performance. SSRN Electronic Journal. 2012.

24. Xu N., Xu X., Yuan Q. Political connections, financing friction, and corporate investment: Evidence from Chinese listed family firms. European Financial Management. 2013;19(4):675-702. DOI: 10.1111/j.1468-036X.2011.00591.x

25. Zhao X., Wan D., Xu H. Political connections and the efficiency of capital allocation through bond financing in Chinese listed companies. Emerging Markets Finance \& Trade. 2013;49(2):158-170. DOI: 10.2753/REE1540-496X4902S209
26. Geng Z. Political connections and investment efficiency: Evidence from Chinese listed private firms. Master thesis. Tilburg University. 2013. 45 p. URL: http://arno.uvt.nl/show.cgi?fid=131551

27. Jing H., Long-Bing X. Political connection and investment efficiency for Chinese overseas firms. Economic Management Journal. 2012;1(8).

28. Chen F., Hope O.-K., Li Q., Wang X. Financial reporting quality and investment efficiency of private firms in emerging markets. The Accounting Review. 2011;86(4):1255-1288. DOI: $10.2308 /$ accr- 10040

29. Richardson S. Over-investment of free cash flow. Review of Accounting Studies. 2006;11(2-3):159-189. DOI: $10.1007 / \mathrm{s} 11142-006-9012-1$

30. Cherkasova V., Teplova O. Research of impact of financial constraints on investment decisions of companies in emerging capital markets. Korporativnye finansy = Journal of Corporate Finance Research. 2013;7(2):4-21. DOI: 10.17323/j.jcfr.20730438.7.2.2013.4-21 (in Russ.).

31. Xie J. CEO career concerns and investment efficiency: Evidence from China. Emerging Markets Review. 2015;24:149-159. DOI: 10.1016/j.ememar.2015.06.001

32. Wan H., Zhu K., Chen X. Career concerns, shareholder monitoring and investment efficiency: From the perspective of compensation contract rigidity in Chinese SOEs. China Journal of Accounting Research. 2015;8(1):59-73. DOI: 10.1016/j.cjar.2015.01.003 